\title{
Agnieszka Malarewicz-Jakubów
}

University of Bialystok, Poland

ORCID: 0000-0001-5964-4546

malarewicz@uwb.edu.pl

\section{Damian Gierasimczuk}

University of Bialystok, Poland

ORCID: 0000-0003-2449-3236

gierasimczuk.d@gmail.com

\section{The Legal Nature of the Judgement Issued Pursuant to Article 425 of the Code of Commercial Companies: Declaratory or Constitutive?}

\author{
Charakter prawny wyroku wydanego na podstawie art. 425 Kodeksu \\ spółek handlowych: deklaratoryjny czy konstytutywny?
}

\begin{abstract}
For many years there has been a dispute in the field of commercial law concerning the nature of the ruling issued as part of an action for annulment of a resolution of the general meeting under Article 425 of the Code of Commercial Companies (hereinafter: CCC). The multitude of both studies of the representatives of the doctrine and opinions expressed in the court decisions, allows this dispute to be included in two opposing theses, which, together with the arguments for their support, the authors presented in this article. The supporters of the declarative character of the judgement indicate the necessity to carry out a linguistic, systemic and historical interpretation of the norm, as well as to refer to Article 58 of the Civil Code and adopt the indicated model of absolute nullity. Part of the doctrine also indicates that the standard of Article 425 CCC is a special regulation in relation to Article 189 of the Code of Civil Procedure. On the side of the thesis about the constitutive ruling, it is indicated that Article 425 CCC is a special regulation in relation to Article $58 \mathrm{CCC}$, and therefore it is not of absolute nullity nature. Moreover, arguments are also raised about the concurrence with the sanction contained in Article 422
\end{abstract}

CORRESPONDENCE ADDRESS: Agnieszka Malarewicz-Jakubów, PhD, Dr. habil., Full Professor, University of Bialystok, Faculty of Law, Department of Civil and Commercial Law, Mickiewicza 1, 15-213 Bialystok; Damian Gierasimczuk, Master of Law, University of Bialystok, Faculty of Law, Department of Civil and Commercial Law, Mickiewicza 1, 15-213 Bialystok. 
Agnieszka Malarewicz-Jakubów, Damian Gierasimczuk

$\mathrm{CCC}$ and about the necessity to secure legal turnover thanks to a constitutive ruling. The article also presents the evolution of the jurisprudence line towards the adoption of a constitutive position and its domination in the jurisprudence of the Polish Supreme Court based on the security of legal transactions. The authors of this article, through the analysis of the Polish jurisprudence as well as the views of the doctrine contained in the comments, scientific articles and monographs, have set themselves the goal of collecting, summarizing and organizing the most popular positions and their arguments.

Keywords: commercial law; annulment of the resolution; general meeting; action for the annulment of a resolution; declaratory; constitutive

\section{INTRODUCTION}

For many years, the science of commercial law has witnessed a dispute about the nature of a ruling issued in the action for declaration of invalidity of a resolution of the general meeting under Article 425 of the Code of Commercial Companies. ${ }^{1}$ Considering plentitude of both studies published by the doctrine's representatives and opinions expressed in judicial rulings, this dispute could be approached from the perspective of two opposite theses. The purpose of this article is to present polarization of opinions in the dispute and outline arguments used by the supporters of a declaratory nature of a ruling declaring invalidity of a resolution as well as by those supporting a constitutive nature of such a ruling. Over the years, this issue has been evolving alongside different approaches. Currently, the strongest polarization can be discerned between the most recent case law and doctrine's representatives. The article presents both points of view and indicates progressive changes in the perception of certain arguments, mainly related to the Polish Supreme Court's judicature. In addition, an analysis of the contact points and differences in the doctrine positions contained in commentaries, scientific articles, monographs and glosses was carried out, and the case law was reviewed.

\section{THE POSITION ON A DECLARATORY NATURE OF A RULING DECLARING INVALIDITY OF A RESOLUTION}

The first opinion in favor of a declaratory nature of a ruling declaring invalidity of a resolution of the general meeting is held by the co-creator of the provisions of the Code of Commercial Companies - S. Sołtysiński. ${ }^{2}$ He believes that we should

${ }^{1}$ Act of 15 September 2000 - Code of Commercial Companies (Journal of Laws 2000, no. 94, item 1037, as amended), hereinafter: CCC.

${ }^{2}$ S. Sołtysiński, Nieważne $i$ wzruszalne uchwały zgromadzeń spótek kapitałowych, "Przegląd Prawa Handlowego" 2006, no. 1, pp. 10-12; idem, [in:] System Prawa Prywatnego, vol. 17B: Prawo spółek kapitałowych, ed. S. Sołtysiński Warszawa 2016, p. 705 ff. 
rely therein on the wording of Article $58 \S 1$ of the Civil Code, ${ }^{3}$ which implies absolute invalidity of a legal act pursuant to the application of Article 2 sentence 1 CCC. Such a structure would foster security of economic and legal transactions because the law prohibits implementation of the general meeting's decisions if a resolution to be executed is defective. Such a resolution must be obligatorily challenged. If the nature of a ruling was constitutive, we would deal with negative consequences in the practice involving "encouragement to adopt unlawful resolutions and carry out dishonest corporate actions whose effects are often impossible to revoke or remedy after several years". Furthermore, S. Sołtysiński deducts from the linguistic interpretation that the legal action brought under Article $425 \mathrm{CCC}$ is the action for declaration of invalidity where the term "declaration" reflects a declaratory nature of a ruling. However, he underlines that invalidity envisaged in the provisions of the Code of Commercial Companies is not the same as invalidity that is classically understood under the provisions of the Civil Code. Invalidity of a resolution is based solely on the prerequisite of a conflict with a resolution, which excludes the application of the prerequisite of circumvention of the law and conflict with the principles of community life and decency in the meaning of the principle lex specialis derogat legi generali. Hence, he concludes that such a resolution is invalid since the moment of its adoption and, ex lege, it does not evoke intended legal effects. The court's ruling on Article $425 \mathrm{CCC}$ should be recognized as declaratory.

A similar opinion is held by A. Kidyba, ${ }^{4}$ who claims that the nature of the action brought under Article $425 \mathrm{CCC}$ is declaratory and it exerts effects with retroactive force from the moment of the resolution's adoption. This opinion is based, most of all, on the interpretation of Article $58 \mathrm{CC}$ applied in conjunction with Article 2 CCC. Pointing to the essence of the sanction of absolute invalidity, A. Kidyba maintains that it operates with retroactive force. This entails that a ruling can only be of a declaratory nature. A different recognition of the ruling's nature, and thus a different understanding of the sanction of absolute invalidity, would efface differences between the action for revocation and the action for declaration of invalidity of a resolution. This would question the relevance of dividing the causes of the action pursuant to the systemic interpretation, which, as a rule, should differentiate between these two grounds (causes). Furthermore, this is justified by the historical interpretation, wherein the legislator purposefully introduced a dual course of

\footnotetext{
3 Act of 23 April 1964 - Civil Code (Journal of Laws 1964, no. 16, item 93, as amended), hereinafter: $\mathrm{CC}$.

4 A. Kidyba, Komentarz do art. 425 k.s.h., [in:] Komentarz aktualizowany do Art. 301-633 Kodeksu spótek handlowych, LEX/el. 2020 (leagl status as of 31 March 2020); A. Kidyba, M. Dumkiewicz, Konstytutywny charakter wyroku sądu stwierdzającego nieważność sprzecznej z umowa uchwały wspólników; zaskarżenie uchwały spótki - glosa - III CZP 13/13, "Monitor Prawa Handlowego" 2015 , no. 1 , p. $38 \mathrm{ff}$.
} 
challenging resolutions while creating the provisions of the Code of Commercial Companies. Hence, he renounced a previous solution resulting from Article 240 of the Commercial Code, which envisaged one cause of the action for revocation of a resolution, not dividing it into the conflict between a resolution and the provisions of law or the provisions of a partnership (company) agreement. To support this thesis of a non-accidental division of the action's causes, A. Kidyba invokes a fragment of the reasoning to the Code of Commercial Companies' draft, according to which "there is a distinction between challengeable resolutions which require a resolution to be revoked $[\ldots]$ and unlawful resolutions which are absolutely invalid". 5

Similar to this, in M. Gutowski's opinion, ${ }^{6}$ the above-mentioned issue is based on the interpretation of Article $58 \mathrm{CC}$ in conjunction with Article $2 \mathrm{CCC}$. As he claims, both the Civil Codes' regulation and Article $425 \mathrm{CCC}$ understand the term "invalidity" analogically, i.e. implying the classic meaning of absolute invalidity. Moreover, applying a linguistic interpretation, the term "declaration of invalidity" would have to be recognized as indication of a declaratory ruling which confirms already existing state of affairs. It would be further supported by the regulations contained in Article $70^{5}$ and Article $388 \S 1 \mathrm{CC}$, which use the term "demand for invalidity" a contrario to the term "declaration of invalidity". Additionally, to justify a declarative nature of a ruling and, consequently, absolute invalidity of a resolution, M. Gutowski invokes Article $425 \S 4 \mathrm{CCC}$, which envisages a possibility of raising an objection of resolution's invalidity. In the case of relative invalidity, a possibility of taking advantage of the objection would be excluded. The very fact itself that a party is equipped with the objection as a form of the defendant's protection determines the nature of the sanction of absolute invalidity in compliance with the feature $a b$ initio and ex lege.

A comprehensive analysis of Article $425 \mathrm{CCC}$ has also been made by R. Pabis, who assumes that a ruling issued on this legal basis should be regarded as declaratory in nature. ${ }^{7}$ It is based on the assumption of the construction of absolute invalidity from Article $58 \S 1 \mathrm{CC}$, which sanction occurs from the very beginning of the act, and its effects may be invoked by anyone without any temporal limitations. R. Pabis first of all points to the linguistic interpretation of the provision, using the notion of "confirmation" and comparing it to the institution of appointing purchasers of an inheritance or confirmation of acquisitive prescription, i.e. events that have already taken place, while the action taken is only supposed to confirm them. He also points

${ }^{5}$ Ministerstwo Sprawiedliwości, Kodeks spółek handlowych. Projekt, Warszawa 1999, p. 295.

${ }^{6}$ M. Gutowski, Sankcja nieważności na tle uchwał organów spótek kapitałowych, "Przegląd Prawa Handlowego" 2007, no. 12, p. 22; idem, Wzruszalność czynności prawnej, Warszawa 2019, p. $241 \mathrm{ff}$.

7 R. Pabis, Komentarz do art. 425 k.s.h., [in:] Kodeks spótek handlowych, vol. 3B: Spótka akcyjna. Komentarz. Art. 393-490, ed. A. Opalski, Warszawa 2016. 
to the clear dualism of actions leading to the liquidation of a resolution in trading mentioned in the justification of the Code of Commercial Companies' draft, taking the standpoint presented by S. Sołtysiński. R. Pabis, referring to the features of absolute invalidity widely recognized in the doctrine, points out that Article 425 CCC is not an independent basis for invalidity referred to by the supporters of the thesis of constitutive character of a judgement, and the source of invalidity is precisely Article 58 \& $1 \mathrm{CC}$ applied by reference from Article 2 CCC.

The necessity to apply Article $58 \mathrm{CC}$ in conjunction with Article $2 \mathrm{CCC}$ is also denoted by J.P. Naworski. ${ }^{8}$ In his opinion, it is the only proper structure as far as the nature of a ruling on declaration of invalidity is concerned. This results both from the systemic and linguistic interpretation and the nature of absolute invalidity in the case of a resolution which is affected with such invalidity under the law and from the moment of its adoption.

A. Zbiegień-Turzańska also supports the declaratory approach in her monographic study, at the same time supporting the link between the nature of the ruling and the construction of absolute invalidity. She states that the assumptions adopted in the institution of absolute invalidity cause that the sanction occurs ex lege, and consequently the court ruling does not shape the sanction itself, but only confirms it. The connection between absolute nullity and the nature of a judgement declaring a resolution invalid leads the author to conclude that a resolution invalid by operation of law and with ex tunc effect is only confirmed by a declaratory ruling of the court. ${ }^{9}$

A declarative nature of a ruling is also implied by R. Flejszar and S. Koczur. ${ }^{10}$ They invoke in their articles the comparison of the structure of the action for declaration of resolution's invalidity with a declaratory action under Article 189 of the Code of Civil Procedure. ${ }^{11}$ The authors believe it is a special regulation, which is a narrowly specified type of a declaratory action. Additionally, they point out that the action under Article $425 \mathrm{CCC}$ is the action that has been purposefully structured in opposition to the action for revocation of a resolution under Article 422 CCC which, in turn, is a type of action for the formation. In their opinion, a declarative nature of a judicial ruling is fully justified by the reliance on the structure and nature of Article 189 CCP. A ruling on admitting the action based on Article 425 CCC exerts the ex tunc effect and, consequently, eliminates an unlawful resolution from

8 J.P. Naworski, [in:] Kodeks spółek handlowych. Komentarz, vol. 3: Tytuł III. Spótki kapitałowe. Dziat II. Spótka akcyjna, eds. T. Siemiątkowski, R. Potrzeszcz, Warszawa 2013, p. 1029.

${ }^{9}$ A. Zbiegień-Turzańska, Sankcje wadliwych uchwał zgromadzeń spótek kapitałowych i spótdzielni, Warszawa 2012, p. 365.

${ }^{10}$ R. Flejszar, S. Kocur, Moc wiążaca uchwat organów spółek kapitałowych wobec osób trzecich, "Prawo Spółek" 2009, no. 7-8, p. 2 ff.

11 Act of 17 November 1964 - Code of Civil Procedure (Journal of Laws 1964, no. 43, item 296, as amended), hereinafter: CCP. 
legal transactions. According to R. Flejszar and S. Koczur, the sanction of invalidity under Article $425 \mathrm{CCC}$ cannot be recognized as relative invalidity. Invoking the Supreme Court's resolution of the panel of 7 judges,${ }^{12}$ the authors point out that with regard to unlawful resolutions, i.e. absolutely invalid, we should assume legal fiction of their effectiveness in order to guarantee safety and security of legal transactions, provided the resolution will not be questioned by the actions lodged under the Code of Commercial Companies.

Reliance on a declaratory action under Article 189 CCP is depicted in the article written by A. Jarocha. ${ }^{13} \mathrm{He}$ claims that Article $425 \mathrm{CCC}$ cannot be an inherent ground for a legal action as it is a procedural measure. The objection of resolution's invalidity should be understood as one of possible grounds for another action. Elimination of a resolution through Article $425 \mathrm{CCC}$ itself occurs in the course of a new type of action which, according to A. Jarocha, is not a type of a declaratory action but a completely distinct action which, however, bears structural features of the action lodged under Article 189 CCP. On the other hand, a new type of action envisages a possibility of raising an objection of resolution's invalidity. A. Jarocha further underlines that Article $189 \mathrm{CCP}$ can be applied in order to revoke an unlawful resolution but solely by entities that are not authorized to challenge a resolution under the Code of Commercial Companies. Reliance on the structure of Article 189 CCP means that a ruling on declaration of resolution's unlawfulness is a ruling of a declaratory nature.

A declaratory nature of a ruling issued under Article $425 \mathrm{CCC}$ is also depicted by M. Michalski. ${ }^{14} \mathrm{He}$ contrasts the structure of the action for declaration of invalidity with the action for revocation of a resolution, which is of a constitutive nature. In his opinion, this dualism of measures used to challenge (question) resolutions of shareholders indicates it is necessary to distinguish the effects of the ruling.

A. Rachwa $1^{15}$ has also presented her point of view on a declaratory ruling. Her opinion thereon refers to Article $254 \mathrm{CCC}$ but it is a structural counterpart of Article $425 \mathrm{CCC}$ with regard to the regulation of a limited liability company. The author derives a declaratory nature of a ruling from the systemic interpretation. Dichotomy of procedures used to challenge a resolution of the general meeting should be recognized as the legislator's intent. It means that an unlawful resolution should be deemed as absolutely invalid ex officio and ab initio.

The opinion of judicature on a declaratory ruling was mainly developing at the beginning of the Code of Commercial Companies' validity. The ruling of the

${ }^{12}$ Resolution of the panel of 7 judges of the Supreme Court of 1 March 2007, III CZP 94/06.

13 A. Jarocha, Legitymacja do żądania stwierdzenia przez sąd nieważności uchwał zgromadzenia wspólników (akcjonariuszy), "Prawo Spółek" 2004, no. 12, p. 37.

${ }_{14}$ M. Michalski, [in:] Spółka akcyjna, ed. A. Kidyba, Warszawa 2014, p. 640.

15 A. Rachwał, [in:] System Prawa Handlowego, vol. 2A: Prawo spótek handlowych, ed. A. Szumański, Warszawa 2019, p. 875. 
Supreme Court of 12 July $2002^{16}$ is worth quoting at first. Proceedings on declaration of resolution's invalidity close with "a judicial ruling of a declaratory nature, which means that the resolution has been invalid from the beginning". The Court points out that the meaning of the term "invalidation" differs from the meaning of the term "declaration of invalidity". So far, the commercial law (pursuant to the Commercial Code) has been distinct from the civil law and the provisions on revocation of resolutions of shareholders' meetings have been special provisions in relation to Article $58 \S 1 \mathrm{CC}$ because they envisaged a different effect in case of an unlawful resolution. Hence, pursuant to these provisions, the action for invalidation of a resolution has been valid despite the fact that this resolution has been defective (as it has been adopted unlawfully). It is binding as long as the court rules on its invalidity in a constitutive judgement, which means this resolution has been invalid from the beginning. Thus, the action for declaration of resolution's invalidity closed with a ruling of a declaratory nature is not valid.

An important judgement in favor of the thesis of a declaratory nature of a ruling was passed by the Constitutional Tribunal on 21 June 2005. ${ }^{17}$ Pursuant to the judgement's wording, the Constitutional Tribunal decided that the action for declaration of resolution's invalidity applies: when the objection concerns resolutions that are unlawful; if their wording, form or adoption are inconsistent with the law (by the provision that is absolutely binding); if resolutions are invalid under the law, the court then issues a declaratory ruling. However, the opinion implying a declaratory nature of a ruling has not been discussed in more detail - the Tribunal has only asserted this nature without plunging into polemic.

In its judgement of 31 March 2006, the Supreme Court decided that a judgement passed in result of the action for declaration of invalidity under Article 252 (425) CCC is declaratory. ${ }^{18}$ The effects of the ruling refer to the moment of the resolution's adoption. The Supreme Court pointed out that if the thesis on a constitutive ruling had been recognized, it would have been useless to regulate the appropriate application of Article $254 \S 2$. In that case, the provisions would have been applied straightforwardly. An additional argument is a possibility of raising an objection of resolution's invalidity without the necessity to obtain a prior ruling.

One of the most recent rulings in favor of a declaratory nature of a judgement is the judgement of the Supreme Court of 6 February 2013 ${ }^{19}$ Examining the appeal on unlawful lowering and establishing remuneration for the cancellation of shares, the Supreme Court decided that a proper procedure is an action under Article 252 CCC. The ruling admitting such action is of a declaratory nature and it merely

\footnotetext{
16 Judgement of the Supreme Court of 12 July 2002, V CKN 1547/00.

17 Judgement of the Constitutional Tribunal Ruling of 21 June 2005, P 25/02.

18 Judgement of the Supreme Court of 31 March 2006, IV CSK 46/05.

19 Judgement of the Supreme Court of 6 February 2013, V CSK 147/12.
} 
Pobrane z czasopisma Studia Iuridica Lublinensia http://studiaiuridica.umcs.pl Data: 26/04/2023 16:25:41

Agnieszka Malarewicz-Jakubów, Damian Gierasimczuk

confirms the existence of a resolution whose content is against the law. On the other hand, not a constitutive ruling but a declaration saying that a performed act is unlawful can justify the assumption that the act has been performed illegally in the meaning of the provisions on tort liability.

\section{THE POSITION ON A CONSTITUTIVE NATURE OF A RULING DECLARING RESOLUTION'S INVALIDITY}

J. Szwaja believes that declaration of resolution's invalidity occurs through the challenge of a resolution and, in consequence, a constitutive judicial ruling. ${ }^{20}$ In his opinion, invalidity does not occur ex lege. He further underlines, however, that the application of a linguistic interpretation of Article $425 \mathrm{CCC}$ can lead to the recognition that a judicial ruling in this matter is declaratory while the ruling merely "formally and officially" declares invalidity of a resolution. J. Szwaja points out that the regulation of Article $425 \S 1$ sentence 1 CCC cannot be interpreted on the basis of Article $58 \mathrm{CC}$, and it does not have the features of absolute invalidity mentioned therein. The action for declaration of resolution's invalidity is a special provision in relation to the Civil Code's regulation, which is a general norm. Moreover, J. Szwaja observes that Article $425 \mathrm{CCC}$ is just this special provision indicated by Article $58 \mathrm{CC}$ which envisages a different effect of an act performed illegally or performed to circumvent the law.

J. Frąckowiak ${ }^{21}$ holds a similar opinion. He believes that Article $425 \mathrm{CCC}$ is an appropriate provision which specifies a distinct nature of the sanction pursuant to Article $58 \S 1 \mathrm{CC}$. He explains that this position is supported by the fact that the regulation of a possibility of bringing action for declaration of invalidity has been limited by a temporary and subjective prerequisite. Such restrictions of the time and entities authorized to bring action prove relative but not absolute invalidity. According to J. Frąckowiak, if the structure of absolute invalidity was adopted, it would be unclear what would happen to the sanction and a possibility of invoking it if none of the authorized entities brought action for declaration of invalidity. Additionally, he points out that the Code of Commercial Companies does not contain the regulation corresponding to Article $58 \mathrm{CC}$, i.e. indicating absolute invalidity of such a resolution. He further argues that the Board of Directors is always bound to perform a resolution adopted by shareholders. The Board may avoid it solely

20 J. Szwaja, [in:] S. Sołtysiński, A. Szumański, A. Szajkowski, J. Szwaja, Kodeks spótek handlowych, vol. 3: Spółka akcyjna. Komentarz do artykułów 301-490, Warszawa 2013, p. 132.

${ }^{21}$ J. Frąckowiak, Uchwały zgromadzeń wspólników spótek kapitałowych sprzeczne z ustawa, "Przegląd Prawa Handlowego" 2007, no. 11, p. 12. 
under judicial permission expressed in a constitutive ruling issued in the action for declaration of resolution's invalidity that has been brought by the Board themselves.

$\mathrm{K}$. Bilewska and $\mathrm{M}$. Warzecha ${ }^{22}$ also firmly support the thesis of a constitutive nature of a ruling. They claim that the nature of the sanction specified in Article 425 CCC is of relative but not absolute invalidity. They support their arguments, however, by Article $427 \S 4$ in conjunction with Article 427 § 1 CCC. In their opinion, only a valid judgement has a binding force of invoking invalidity of a resolution. As a result of this structure, invalidity of a resolution may be invoked solely and exclusively when a ruling is passed. Hence, it contradicts the theory according to which a resolution is absolutely invalid and its invalidity may be invoked at any time.

A. Pęczyk-Tofel points out that the Code of Commercial Companies envisage two types of invalidity in its provisions. ${ }^{23}$ These are absolutely invalid resolutions, which are mentioned, e.g., in Article $6 \S 1 \mathrm{CCC}$, as well as inherent invalidity structured on the basis of Article $425 \mathrm{CCC}$. The argument for such a division is the wording of Article $425 \mathrm{CCC}$. It implies that declaration of invalidity of an unlawful resolution is admissible, and yet it does not determine that such a resolution is invalid. According to A. Pęczyk-Tofel, the sanction formed on the basis of the action for declaration of invalidity is concurrent with the sanction based on Article 422 CCC, i.e. relative invalidity. Additionally, she underlines that "clear and univocal results of a literal interpretation should not be modified by reference to arguments resulting from a functional or systemic interpretation".

In his article, A. Koch denotes that resolution's invalidity could be invoked only when a constitutive ruling adjudicating its invalidity has already been passed. ${ }^{24} \mathrm{He}$ argues that absolute invalidity of a resolution must be characterized by invalidity ex officio and ab initio, whereas the sanction itself can be invoked by anyone at any time. With regard to the regulation of Article $425 \mathrm{CCC}$, it limits a group of authorized entities and sets time limits for invoking invalidity. This, actually, contradicts the essence of absolute invalidity. On the other hand, the adoption of the structure of a declaratory ruling would contradict the relevance of introducing the regulation of Article $425 \mathrm{CCC}$. The author believes that the structure of the action for declaration of resolution's invalidity and the adoption of the model of relative invalidity prevent manifestations of excessive discretion to the extent of the assessment of resolutions' effectiveness. Hence, the resolutions stabilize internal relations in a company and secure transactions. It should also be pointed

${ }^{22}$ K. Bilewska, M. Warzecha, Dopuszczalność stosowania Art. 58 \$ 3 k.c. do uchwat zgromadzeń spótek kapitałowych - polemika, "Przegląd Prawa Handlowego" 2010, no. 7, p. 55.

${ }^{23}$ A. Pęczyk-Tofel, Nieważne i podlegające stwierdzeniu nieważności uchwały walnego zgromadzenia spótki komandytowo-akcyjnej, "Przegląd Prawa Handlowego" 2009, no. 11, p. 22.

${ }^{24}$ A. Koch, Charakter sankcji wobec sprzecznych z prawem uchwat spótek kapitałowych, "Przegląd Prawa Handlowego" 2007, no. 2, p. 4 ff. 
out that according to A. Koch the constitutive nature of a ruling is also manifested when the court analyzes the issues affecting the invalidity of a resolution, making findings and assessments in this respect. Such a creative approach of the court to the problem indicates constitutive nature of a ruling as a result of autonomous discretion of the court. ${ }^{25}$

A. Szumański may be an example of the evolution of opinions towards a constitutive nature of a ruling and relative invalidity. In his initial publications, he clearly denoted that a resolution inconsistent with the provisions that are absolutely binding is invalid ex lege and from the beginning of its adoption whereas a ruling adjudicating its invalidly is of a declaratory nature ${ }^{26}$ It appears, however, that together with a change in judicial decisions issued by the Supreme Court on this matter, A. Szumański has updated his opinion too. It seems that this change took place when the Supreme Court issued a landmark resolution of the panel of 7 judges (III CZP 94/06). In the study of 2012, A. Szumański supports the most recent judicial opinions implying relative invalidity of an unlawful resolution. ${ }^{27} \mathrm{He}$ points out that a simple application of Article $58 \mathrm{CC}$ in conjunction with Article 2 $\mathrm{CCC}$ cannot be made in relation to the structure of the company law. Instead, one should rely on the inherent Code of Commercial Companies regulation in the form of Article 425 thereof. Pursuant to the case law, this inherence is manifested, above all, in the sanctioned defectiveness of a resolution which is a subject of a ruling of a constitutive nature. The application of the structure based on absolute invalidity would threaten security of legal transactions. Whereas Article $58 \mathrm{CC}$ itself points to other provisions regulating the issue of invalidity separately. A. Szumański underlines that Article 425, Article 21, Article 497 § 2 or Article 532 § 3 CCC should be recognized as such norms.

P. Ochmann ${ }^{28}$ relies thereon on case law as well. It should be emphasized that this opinion is, above all, characterized by pragmatism resulting from the approach adopted by the practice (such as quite established Supreme Court's case law) with regard to this issue. Quoting two significant resolutions of the Supreme Court: III CZP 96/06 and III CZP 13/13, he underlines that a constitutive nature of a ruling declaring invalidity of a resolution should be left undisputed - this thesis will still prevail in judicial decisions made by the courts of the first and second instance.

${ }^{25}$ Idem, Podważanie uchwał zgromadzeń spółek kapitałowych, Warszawa 2011, pp. 118-119.

26 A. Szumański, [in:] W. Pyzioł, A. Szumański, I. Weiss, Prawo spótek, Bydgoszcz-Kraków 2006, p. 731.

${ }^{27}$ Idem, Specyfika nieważności czynności prawnej w prawie spótek handlowych, [in:] Rozprawy z prawa cywilnego, własności intelektualnej i prawa prywatnego międzynarodowego. Księga pamiątkowa dedykowana Prof. Bogusławowi Gawlikowi, eds. J. Pisuliński, P. Tereszkiewicz, F. Zoll, Warszawa 2012, p. $559 \mathrm{ff}$.

${ }^{28}$ P. Ochmann, Uchwaty nieistniejące wobec sankcji nieważności wadliwych uchwał zgromadzeń spółek kapitałowych, Warszawa 2018, p. 119 ff. 
However, the author puts forward his own thesis on the nature of the sanction which affects an unlawful resolution. In his opinion, the application of Article $58 \mathrm{CC}$ is excluded because it does not correspond to the nature of corporate resolutions. Article 425 CCC, on the other hand, is an inherent ground thereto. With regard to the resolutions mentioned in Article $422 \mathrm{CCC}$, it can be noticed that they are characterized by relative invalidity whereas unlawful resolutions are suspended between the model structure of mutability and absolute invalidity. Above all, P. Ochmann denotes that the regulation of the matter of unlawful resolutions is complete, which excludes reference to the Civil Code through Article $2 \mathrm{CCC}$. He further argues that the regulation of the Code of Commercial Companies determines a group of entities authorized to make a challenge and sets temporary limits. In order to remove a resolution from legal transactions, however, it is necessary to carry out several actions beforehand, i.e. lodge the action and pronounce a ruling declaring invalidity. This, in turn, excludes a possibility of invoking resolution invalidity at any time.

Judicature can boast quite well-established position thereon, which has been persistently maintained for a few years. Nevertheless, it is not entirely uniform, which is exemplified by rulings in favor of the thesis of a declarative nature of a judgement. The Supreme Court, in the resolution of 17 February 2004 (III CZP 116/03) - one of its first resolutions discussing the issue of a constitutive nature of a ruling - ruled that while the nature of a ruling passed in a result of an action for revocation of a resolution of shareholders is undisputed, the action for declaration of invalidity is more complex. This resolution indicates that invalidity determined under Article $252 \S 1$ (Article 425) CCC is rather a special regulation in relation to Article $58 \mathrm{CC}$. It means that invalidity of such a resolution should be deemed as relative and not absolute invalidity. This is further supported by the introduction of the catalogue of entities authorized to bring legal action and the time to lodge it. According to the Supreme Court, the adoption of the classic structure of absolute invalidity would threaten security of legal transactions due to a possibility of raising an objection of invalidity by any person at any time. At the same time, however, the Supreme Court underlines that the structure of Article $242 \S 4 \mathrm{CCC}$ weakens the position on a constitutive ruling, but, nevertheless, it does not refer to Article 425 CCC.

At present, one of the most important resolutions is the resolution of the panel of 7 judges of the Supreme Court of 1 March 2007 (III CZP 94/06), which has acquired an attribute of a legal rule. The Supreme Court has univocally decided that a dispute about the sanction is independent of the nature of a ruling passed in the action for declaration of invalidity. It has been underlined that neither Article 58 CC nor Article 252 CCC should be excluded as a source of invalidity. Each of these grounds can be a source of invalidity of an unlawful resolution, whether it is classically understood absolute invalidity regulated in the Civil Code or modified invalidity contained in the Code of Commercial Companies. According to the Supreme Court, regardless of the adoption of the above-mentioned sanctions, a ruling 
of the court declaring invalidity will be a ruling of a constitutive nature due to the necessity of protecting certainty and security of legal transactions. A valid ruling is a sole proof (confirmation) of the existence of the effect in the form of invalidity whereas such a ruling exerts the effect ex tunc. The Supreme Court indicates that before initiating proceedings and during pending proceedings, it should be assumed that a resolution exerts legal effects, which should not be negated even if it is highly probable that such a resolution would be recognized as invalid.

The second most important resolution of the Supreme Court, and at the same time the most up-to-date one, is the resolution of the panel of 7 judges of the Supreme Court of 18 September 2013 (III CZP 13/13). The Court firmly decided that a judicial ruling declaring invalidity of an unlawful resolution that had been taken by the general meeting of a joint-stock company is of a constitutive nature. The Supreme Court points out that Article $425 \mathrm{CCC}$ is a complete and special regulation in relation to Article $58 \mathrm{CC}$, therefore, it creates a special regulation of invalidity, in particular as a result of containing therein a group of authorized entities and time limits, at the same time approaching relative invalidity to a large extent. Additionally, a constitutive nature of a ruling is also supported by the excluded possibility of the application of Article $189 \mathrm{CCP}$, which is generally used to initiate action for declaration of absolute invalidity of a given act. It means that the legislator reserved a distinct (different) sanction in Article 425 CCC, i.e. mutability of an unlawful resolution. Hence, attributing the ex tunc feature to a ruling does not support the thesis according to which such a resolution is invalid from the very beginning. The Supreme Court emphasizes the importance of regulations' flexibility in relation to commercial transactions and guarantee of their security, stability and certainty to contractors. Such flexibility is assured by the adoption of the concept of a constitutive ruling. The thesis of a declarative nature of a ruling would threaten transactions' participants with uncertainty related with contractors' actions and decisions, and thus greatly increasing legal risk. Moreover, the courts taking into account ex officio, without time limitations, absolute invalidity would deepen the feeling of instability in trading. In the Supreme Court's view, the resolution is a kind of culmination of the divergences arising in the case law, but it did not influence the adoption of a similar stance in the literature. It should be noted that due to the controversial nature of the problem and apparent polarization of positions, the Supreme Court indicated the necessity for necessary and competent resolution of the dispute by legislative intervention, thus eliminating any divergences.

The Supreme Court's case law appears to follow the above-mentioned resolutions. An apparent example thereof could be, among others, the Supreme Court's judgement of 18 April 2019 (II CSK 197/18). ${ }^{29}$ In the Court's opinion, the regu-

${ }^{29}$ Analogous reasoning in: judgement of the Supreme Court of 10 November 2020, V CSK 518/18; judgement of the Supreme Court of 9 July 2020, V CSK 495/18; judgement of the Supreme 
lation of Article 252 (425) CCC is a different effect envisaged in accordance with Article $58 \mathrm{CC}$, therefore, it is a special form of the sanction of invalidity in relation to the classic structure of absolute invalidity. Most of all, the Court finds a constitutive nature of a ruling declaring invalidity of a resolution as distinctiveness. In its reasoning, the Court invokes, above all, the resolution of the Supreme Court of 18 September 2013. For the security of transactions, only a valid ruling may eliminate an unlawful resolution.

A practical problem that may arise in connection with the constitutive nature of the ruling is the application of Article 23 of the Act 20 August 1997 on the National Court Register. ${ }^{30}$ According to it, the registration court, when examining the documents attached to the application for entry in terms of form and content compliant with the provisions of law, may refuse entry on the grounds that they are contrary to the law. Referring this right to a resolution attached to the application and being in conflict with mandatory provisions of law, it is argued that the registration court will have the possibility to declare such resolution invalid, and at the same time refuse entry, regardless of the action for invalidation. ${ }^{31}$ It is pointed out, however, that this statement is not effective erga omnes. It is argued that it is not possible to invoke invalidity in proceedings other than registration proceedings, which, if accepted otherwise, would devalue the role of Article $425 \mathrm{CCC}$, leading to a constitutive judgement on the invalidity of a resolution only thanks to a judgement of the registration court, which could be used in trading and before other proceedings. ${ }^{32}$

\section{CONCLUSIONS}

Both theses, i.e. on a declaratory and constitutive nature of a ruling issued on the basis of the action lodged under Article $425 \mathrm{CCC}$, are supported by a wide group of proponents and opponents. The apparent division, however, occurs between the doctrine and judicature. Prof. S. Sołtysiński, Nestor of modern Polish commercial law, as well as other representatives of the doctrine, among others Prof. A. Kidyba or M. Gutowski, support the declaratory approach. Additionally, apparent arguments used therein are based on the literal interpretation of the legal provision and systemic interpretation, which is reflected in the reference to the regulation of absolute invalidity contained in the Civil Code and opposition of Article 422 CCC

Court of 1 July 2020, I UK 416/18; decision of the Supreme Court of 30 June 2020, III CZP 69/19; judgement of the Supreme Court of 18 April 2019, II CSK 197/18; judgement of the Supreme Court of 27 February 2019, II CSK 28/18; judgement of the Supreme Court of 25 May 2017, II CSK 524/16.

30 Journal of Laws 1997, no. 121, item 769, as amended.

${ }^{31}$ Decision of the Supreme Court of 23 July 2013, III CNP 1/13.

32 A. Michnik, Krajowy Rejestr Sąowy. Komentarz, Warszawa 2013, p. 216; W. Popiołek, Komentarz do art. 425 k.s.h., [in:] Kodeks spółek handlowych. Komentarz, ed. J. Strzępka, Warszawa 2015. 
to the action for declaration of resolution's invalidity. In the initial phase of the new Code's existence, case law seemed to follow the voice of the doctrine until first rulings and resolutions supporting a constitutive nature were passed. On the other hand, one cannot disregard far-reaching pragmatism of judicature's argumentation and their will to secure transactions and their participants. Nevertheless, in both theses, there appear opinions on the need to separate the sanction affecting an unlawful resolution from the nature of a ruling.

\section{REFERENCES}

\section{Literature}

Bilewska K., Warzecha M., Dopuszczalność stosowania Art. 58 \& 3 k.c. do uchwat zgromadzeń spółek kapitałowych - polemika, "Przegląd Prawa Handlowego" 2010, no. 7.

Flejszar R., Kocur S., Moc wiążąca uchwat organów spółek kapitałowych wobec osób trzecich, "Prawo Spółek" 2009, no. 7-8.

Frąckowiak J., Uchwały zgromadzeń wspólników spółek kapitałowych sprzeczne z ustawa, "Przegląd Prawa Handlowego" 2007, no. 11.

Gutowski M., Sankcja nieważności na tle uchwał organów spółek kapitałowych, "Przegląd Prawa Handlowego" 2007, no. 12.

Gutowski M., Wzruszalność czynności prawnej, Warszawa 2019.

Jarocha A., Legitymacja do żądania stwierdzenia przez sąd nieważności uchwał zgromadzenia wspólników (akcjonariuszy), "Prawo Spółek" 2004, no. 12.

Kidyba A., Komentarz do art. 425 k.s.h., [in:] Komentarz aktualizowany do Art. 301-633 Kodeksu spótek handlowych, LEX/el. 2020 (legal status as of 31 March 2020).

Kidyba A., Dumkiewicz M., Konstytutywny charakter wyroku sadu stwierdzającego nieważność sprzecznej z umowa uchwaty wspólników; zaskarżenie uchwały spótki-glosa-III CZP 13/13, "Monitor Prawa Handlowego" 2015, no. 1.

Koch A., Charakter sankcji wobec sprzecznych z prawem uchwat spótek kapitałowych, "Przegląd Prawa Handlowego" 2007, no. 2.

Koch A., Podważanie uchwat zgromadzeń spótek kapitałowych, Warszawa 2011.

Michalski M., [in:] Spótka akcyjna, ed. A. Kidyba, Warszawa 2014.

Michnik A., Krajowy Rejestr Sadowy. Komentarz, Warszawa 2013.

Ministerstwo Sprawiedliwości, Kodeks spótek handlowych. Projekt, Warszawa 1999.

Naworski J.P., [in:] Kodeks spółek handlowych. Komentarz, vol. 3: Tytuł III. Spółki kapitałowe. Dziat II. Spółka akcyjna, eds. T. Siemiątkowski, R. Potrzeszcz, Warszawa 2013.

Ochmann P., Uchwały nieistniejące wobec sankcji nieważności wadliwych uchwat zgromadzeń spótek kapitałowych, Warszawa 2018.

Pabis R., Komentarz do art. 425 k.s.h., [in:] Kodeks spółek handlowych, vol. 3B: Spółka akcyjna. Komentarz. Art. 393-490, ed. A. Opalski, Warszawa 2016.

Pęczyk-Tofel A., Nieważne i podlegające stwierdzeniu nieważności uchwały walnego zgromadzenia spółki komandytowo-akcyjnej, "Przegląd Prawa Handlowego" 2009, no. 11.

Popiołek W., Komentarz do art. 425 k.s.h., [in:] Kodeks spólek handlowych. Komentarz, ed. J. Strzępka, Warszawa 2015.

Rachwał A., [in:] System Prawa Handlowego, vol. 2A: Prawo spótek handlowych, ed. A. Szumański, Warszawa 2019. 
Sołtysiński S., [in:] System Prawa Prywatnego, vol. 17B: Prawo spółek kapitałowych, ed. S. Sołtysiński Warszawa 2016.

Sołtysiński S., Nieważne i wzruszalne uchwały zgromadzeń spółek kapitałowych, "Przegląd Prawa Handlowego" 2006, no. 1.

Szumański A., [in:] W. Pyzioł, A. Szumański, I. Weiss, Prawo spółek, Bydgoszcz-Kraków 2006.

Szumański A., Specyfika nieważności czynności prawnej w prawie spółek handlowych, [in:] Rozprawy z prawa cywilnego, własności intelektualnej i prawa prywatnego międzynarodowego. Księga pamiątkowa dedykowana Prof. Bogusławowi Gawlikowi, eds. J. Pisuliński, P. Tereszkiewicz, F. Zoll, Warszawa 2012.

Szwaja J., [in:] S. Sołtysiński, A. Szumański, A. Szajkowski, J. Szwaja, Kodeks spótek handlowych, vol. 3: Spótka akcyjna. Komentarz do artykułów 301-490, Warszawa 2013.

Zbiegień-Turzańska A., Sankcje wadliwych uchwat zgromadzeń spółek kapitałowych i spółdzielni, Warszawa 2012.

\section{Legal acts}

Act of 23 April 1964 - Civil Code (Journal of Laws 1964, no. 16, item 93, as amended).

Act of 17 November 1964 - Code of Civil Procedure (Journal of Laws 1964, no. 43, item 296, as amended).

Act of 20 August 1997 on the National Court Register (Journal of Laws 1997, no. 121, item 769, as amended).

Act of 15 September 2000 - Code of Commercial Companies (Journal of Laws 2000, no. 94, item 1037, as amended).

\section{Case law}

Decision of the Supreme Court of 23 July 2013, III CNP 1/13.

Decision of the Supreme Court of 30 June 2020, III CZP 69/19.

Judgement of the Constitutional Tribunal Ruling of 21 June 2005, P 25/02.

Judgement of the Supreme Court of 12 July 2002, V CKN 1547/00.

Judgement of the Supreme Court of 31 March 2006, IV CSK 46/05.

Judgement of the Supreme Court of 6 February 2013, V CSK 147/12.

Judgement of the Supreme Court of 25 May 2017, II CSK 524/16.

Judgement of the Supreme Court of 27 February 2019, II CSK 28/18.

Judgement of the Supreme Court of 18 April 2019, II CSK 197/18.

Judgement of the Supreme Court of 18 April 2020, II CSK 197/18.

Judgement of the Supreme Court of 1 July 2020, I UK 416/18.

Judgement of the Supreme Court of 9 July 2020, V CSK 495/18.

Judgement of the Supreme Court of 10 November 2020, V CSK 518/18.

Resolution of the panel of 7 judges of the Supreme Court of 1 March 2007, III CZP 94/06.

Resolution of the panel of 7 judges of the Supreme Court of 18 September 2013, III CZP 13/13.

Resolution of the Supreme Court of 17 February 2004, III CZP 116/03. 
Pobrane z czasopisma Studia Iuridica Lublinensia http://studiaiuridica.umes.pl Data: 26/04/2023 16:25:41

Agnieszka Malarewicz-Jakubów, Damian Gierasimczuk

\begin{abstract}
ABSTRAKT
W nauce prawa handlowego obecny jest od wielu lat spór dotyczący charakteru orzeczenia wydanego w ramach powództwa o stwierdzenie nieważności uchwały walnego zgromadzenia na podstawie art. 425 k.s.h. Mnogość zarówno opracowań przedstawicieli doktryny, jak i stanowisk wyrażonych w orzeczeniach sądowych pozwala spór ten ując w dwóch przeciwstawnych sobie tezach, które wraz z argumentami na ich poparcie autorzy przedstawili w niniejszym artykule. Zwolennicy deklaratywnego charakteru orzeczenia wskazują na konieczność przeprowadzenia wykładni językowej, systemowej i historycznej normy, jak również odwołania się do art. 58 k.c. i przyjęcia wskazanego modelu nieważności bezwzględnej. Część doktryny wskazuje także, że norma z art. 425 k.s.h. jest regulacją szczególną w stosunku do art. 189 k.p.c. Po stronie tezy o konstytutywnym orzeczeniu wskazuje się, że art. 425 k.s.h. jest regulacją szczególną w stosunku do art. 58 k.c., a co za tym idzie nie ma charakteru nieważności bezwzględnej. Ponadto podnoszone są argumenty o zbieżności z sankcją zawartą w art. 422 k.s.h. oraz o konieczności zabezpieczenia obrotu prawnego dzięki konstytutywnemu orzeczeniu. W opracowaniu przybliżono też ewolucję linii orzeczniczej w kierunku przyjęcia stanowiska konstytutywnego i jego dominacji w orzecznictwie Sądu Najwyższego w oparciu o bezpieczeństwo obrotu prawnego. Autorzy - poprzez analizę polskiego orzecznictwa i poglądów doktryny zawartych w komentarzach, artykułach naukowych i monografiach - postawili sobie za cel zebranie, podsumowanie i uporządkowanie najpopularniejszych stanowisk i ich argumentacji.
\end{abstract}

Słowa kluczowe: prawo handlowe; nieważność uchwały; walne zgromadzenie; powództwo o stwierdzenie nieważności uchwały; deklaratoryjność; konstytutywność 